more refrangible than $\mathrm{H} \alpha$, in addition to those usually seen. It was situated about 4 of the distance from $C$ to $D$. If any other observer noted the position of the arch observed at 8 . I 5 P. M. I shall be glad to be informed, in order to calculate the height. Clementhorpe, N. Shields, Oct. 27 Henry R. Proctor

ANOTHER display of aurora borealis occurred this evening It was not to he crmmared in splendour with that of the night preceding, hut it harl some interesting and instructive features. The sky was not clear ar any time, and the masses of red light, which occunied generatly similar situations to those of the preceding night. were interrunted in many places by dense clouds. I oherved it at about half-past six P.M., and at that time the most remarkahle feature was that streamers (generally not of $a$ red colowi) ratiatel from every part of the north horizon accurately to a nnint defined very nearly by one of the stars $\sigma$ Cygni or $v$ Crgni, which were then near the meridian. I did not see both stars, and I am therefore in doubt, as they are of equal magnitules, which was the star nearest to the point of convergence of the streamers.

The rarliations were so well marked and so accurately directed to one point, that I mentally compared them to the ribs of an expanded umbrella. This did not last long; in a few minutes fine strenmers went from the N.W. horizon towards the southeast, to the east of this point, which was then covered with red light without streamers. The largest masses of red light were, as in the preceding evening, south of the zenith, and in the south.east and south-west quarters of the heavens.

Radcliffe Observatory, Oxford, Oct. 25 ROBERT MAIN

A. MAGNIFICENT auroral display was visible here on the evening of the $24 \mathrm{th}_{\mathrm{s}}$, hetween $8^{\mathrm{h}} \mathrm{O}^{\mathrm{m}}$ and $8^{\mathrm{h}} 3 \mathrm{O}^{\mathrm{m}}$.

The maximum of intensicy must have occurred between $8^{\text {h }} \mathrm{O}^{\mathrm{m}}$ and $8^{\mathrm{h}} 20^{\mathrm{r}}$, but, heing otherwise engagect, I did not observe anything myself until $8^{12} 25^{111}$, when the $E$. and W. regions of the sky, more especially the latter, were illuminated with a crimson or reddish glow, somewhat resembling the reflection of distant conflagrations, but on neither side did this glow appear to reach the zenith by many degrees. Shortly after the time mentioned $\left(8^{\mathrm{h}} 25^{-1 m}\right.$ ) both disappeared, after which a phosphorescent whitish light was observed nearer to and on the S.E. of the zenith. The barometer had, during the previous day or two, shown considerable variation in atmospheric pressure.

Another displiay was observed on the following evening (25th), which commenced about $6^{\mathrm{h}} \mathrm{O}^{\mathrm{m}}$ and continued visible more or less until $7^{\mathrm{h}} \mathrm{O}^{\mathrm{m}}$.

The first indication that I noticed was a fiery glow similar to that seen on the previous evening, but considerably higher, and almost inmediately after a magnificent broad stream of light, consisting of reddisti and light tints, was observed in the N.E. extending up wards for $50^{\circ}$ or $60^{\circ}$.

A bout $6^{\mathrm{b}} 20^{\mathrm{m}}$ the whole of the northern region of the sky extending to E-and WV., ancl about $15^{\circ} \mathrm{S}$. of the zenith, was more or less illuminated, and I $s^{2}$ ould say the maximum of intensity occurred at this time. The principal luminous streams and coruscations appeared between N.E. and E.N.E. appearing first in the latter direction and increasing towards the former.

On one occasion I noticed faint luminous streamers rising from different northerly directions and converging in the zenth; these, together with the coloured bands of light befure mentioned, formed a magnificent and imposing spectacle.

The northern sky afterwards presented an appearance of twilight until about $10^{\mathrm{h}} 45^{\mathrm{m}}$.

During the display the barometer stood at 29.53 (corrected for temperature). Temperature of air $49^{\circ}$. The minimum temperature registered during the night was $42^{\circ}$.

Meteorological Observatory, Twickenham Jorn J. HALL

CoLlins, in his "Superstitions of the Highlands" has these lines :-

As Boreas threw his young Aurora forth

In the first year of the first George's reign

And battles raged in welkin of the Narth,

They mourned in air, fell, fell rebellion slain!

The Editor (Routledge's edition) in a note states "By 'young Aurora' Collins undoubtedly means the first appearance of the Northern Lights, which happened about the year I715; at least it is highly probable from the peculiar circumstance that no ancient writer had taken any notice of them, nor even any modern previous to the above date." Can any of your readers state wheticr this is correct.

Poole, Oct. 27

AN aurora borealis was visible at this place on the evening of the 25 th inst., between the hours of 7 and 8.30 P.M. A beaut:ful crimson glow was first observed tuwards the north-east, veiling, but not hiding, the larser stars, and the Pleiades had the appearance of a wedge of pale yellow mist behind the veil. On the horizon, looking due morth, was a semicircular luminous space of clear pale light, of the colour of eastern sky just befure dawn, and from this there darted at intervals over the crimson glow long slender rays of yellowish light, giving on exceedingly beautiful appearance to the phenomenun. Clouds, which hat been hanging about during the day, gathered over the scene towards 9 o'clock, anc when they alterwards dispersed before midnight, the glow, though srill perceptible, was fadms away. A falling star was observed at about eight, but considerably to the south of the aurora. There had been an aurora observed on the preceding evening, but of a less striking character. The weather has been for the last ten days extremely unsettled, sirocco (S.E.) winds prevailing, and an unusual rainfall the result, accompanied somctimes by hail, and by thunder and lightning. But clear bright days occur in the intervals of these storms, when the sky is of an intense blue, ayainst which beautiful forms of cloud mass themselves by de grees as the day goes on. and hecume at length the subjects of those gorgeous atmospheric effects which make the autumnal sunsets of the bay of Fiume rivals of those of Rome.

Fiume, Oct. 28

A. M. SMrfi

[In addition to the letters printed above, we have received from many other correspondents interesting and valuable descriptions of the magnificent display of the aurora, which the demands of other subjects on our space alone prevent us from. publishing.-ED.]

\section{The Aurora of Sept. 24}

Ir may interest your readers to know that the very brilliant aurora of the $24^{t h}$ and $25^{\text {th }}$ September last was also visible in Canada. Mr. W. B. Dawson, writirg from Montreal, notices the occurrence of a vey bright aurora on both nights, flashing much, and of ten bright crimson. It was also seen at Quebec, and attracted much attention. He observes that its appearance was simultaneous with the division of a very large spot on the sun. Its crimson colour agrees with the red hue of your other correspondents; and is somewhat remarkable, as I have often noticerl, in Canada, that the red usually alternates with green in vivid displats.

Koyal School of Mines

\section{Hereditary Deformities}

THE alleged instances of hereditary deformity prodiced by. your correspondent in NATURE for Oct. 20 do not seem at all satisfactory. They may all be referred either to an hereditary disease of the part affected, as in the suppuration of the cow ${ }^{j}$ s horn; or to coincidence, accompanied by a slight stretch of imagination on the part of the first narrator, as in the cases of the scar on the forehead and the crnoked finger.

Prot. If nxley, in his lectures on Natural History at the Royal School of Mines in 1864, after speaking of the short-legged breed of Ancon sheep, and the six-fingered Maltese, Gratio Kelleia, said that although natural malformations were thus transmitted, artificial malformations never were; and instanced the fact of the mutilation produced by circumcision never being transmitted to the ofispring. This, of course, is a negative argument, but it has great weight when we consider how many thousards have undergone that mutilation without an instance of its having been inherited by their children

Faversham, Kent, Oct. 25

WILLIAM FịLI)

\section{The Cefn Reptile and the "Times"}

THE xemarkable paragraph in the Fimes of the week before last relating to the discovery of "a huge beast of the lizard tribe," in a cave at Cefn near St. A saph, implies a belief on the part of the editorial staff that such an addition to the British fauna was not impossible, and its wicle circulation proves the astonishing credulity of the public :-

"In the Vale of Clwyd, at a distance of two miles from the 